\title{
Implementasi STBI “Search Operation” dalam Meningkatkan Literasi Informasi Mahasiswa dalam Pembelajaran Daring
}

\author{
Ratih Desnita Wilanda \\ Perpustakaan dan Ilmu Informasi, Fakultas Bahasa dan Seni, Universitas Negeri Padang \\ ratihdesnitaw24@gmail.com
}

Received : 18 June 2021

Revised : 13 July 2021

Accepted : 19 September 2021 DOI

\begin{abstract}
Information literacy ability is very important possessed by students. It is intended that the information needed can be met properly. This article will discuss the implementation of the STBI "Search Operation" to help students find information according to their needs. This also relates to the online learning process. This article uses a qualitative method using descriptive analysis method. The purpose of this article is to assist students in implementing STBI "Search Operations" and provide an understanding of the effects of "Search Operations" in the online learning process and improve student literacy skills.
\end{abstract}

Keywords: Search Operation, information literacy, online learning

PENDAHULUAN

Kehidupan manusia yang saat ini tergantung pada teknologi membuat teknologi memiliki peran penting dalam segala aspek kehidupan, termasuk dalam pemenuhan informasi. Perkembangan teknologi pada saat ini memiliki pengaruh besar terhadap peertumbuhan dan perkembangan informasi, salah satunya yaitu dalam proses menemukan kembali informasi tersebut. Proses menemukan kembali informasi ini sering disebut dengan proses temu kembali infromasi. Saat ini proses temu kembali informasi sangat dibantu dengan adanya teknologi yang terus mengalami perkemabngan. Teknologi bahkan dijadikan sebagai tolak ukur dalam keakuratan dari informasi yang diperoleh. Adanya teknologi membuat informasi cepat tersebar bahkan sangat mudah didapatkan. Tidak membutuhkan waktu yang lama, dalam hitungan detik perkembangan informasi akan cepat berubah, berbagai macam informasi akan cepat tersebar. Penyebaran informasi yang didukung dengan adanya teknologi adalah peneyebaran informasi secara online.

Banyaknya informasi yang tersebar menuntut ketelitian dan pemahaman terhadap informasi tersebut. Proses temu kembali informasi harus disertai dengan literasi yang kuat, sebab tidak semua informasi tersebut sesauai dengan kebutuhan yang diperlukan. Perlunya literasi informasi disini yaitu dapat memilah informasi yang tersebar dan menyesuaikannya dengan kebutuhan. Hal ini berkaitan dengan kemampuan seseorang untuk mengetahui 
informasi apa yang dibutuhkan dan bagaimana cara pemenuhan dari informasi tersebut. Sebagaimana yang kita tahu informasi yang tersebar memiliki jenis yang berbeda- beda, bahkan dalam satu informasi yang sama dapat ditemukan data yang berbeda. Hal ini tentunya sesuai dengan sudut pandang yang membuat atau yang bertanggung jawab terhadap informasi tersebut. Oleh sebab itulah perlu adanya literasi informasi dalam proses temu kembali informasi. Keberadaan teknologi juga menjadi salah satu hal yang harus dipertimbangkan dalam proses temu kembali informasi. Bahkan dengan banyaknya informasi yang tersebar melalaui teknologi misalnya media masaa, maka literasi informasi harus lebih ditingkatkan lagi.

Teknologi tidak hanya memberikan dampak yang baik terhadap perkembangan teknologi, namun juga memikili dampak yang buruk. Kemudahan dalam mempublish informasi dengan bantuan teknologi, membuat banyak tangan-tangan yang tidak bertanggung jawab menyebarkan infromasi yang tidak benar. Banyaknya infromasi yang tersebar yang sesuai dengan fakta yang ada berbanding seimbang dengan penyebaran informasi yang tidak sesuai dengan fakta yang ada atau atau disebut dengan informasi Hoax. Tidak bisa kita pungkiri saat ini banyak sekali infromasi yang tersebar yang tidak sesuai dengan fakta yang sebenarnya, maka disinilah kemampuan literasi informasi yang dimiliki seseorang untuk dapat diimplementasikan. Dalam proses temu kembali informasi tentu hal ini akan menjadi salah satu kendalanya.

Dalam kehidupan ini kita tidak akan terlepas dari informasi. Informasi dijadikan sebagai petunjuk maupun dijadikan sebagai pemenuhan kebutuhan dasar seseorang, misalnya dalam menempuh jenjang pendidikan. Seperti halnya dalam proses pembelajaran, informasi menjadi hal penting yang setiap hari menjadi kebutuhan yang mendasar. Kembali lagi dalam hal ini teknologi juga memiliki peran penting dan telah berhasil merubah proses pembelajaran menjadi lebih beragam. Saat ini proses pembelajaran tidak hanya dapat dilakukan secara manual atau tatap muka secara langsung, namun dapat dilakukan tanpa adanya batasan seperti proses pembelajaran daring yang sekarang banyak diimplementasikan dalam proses pembelajaran pada perguruan tinggi. Adanya teknologi proses pembelajaran daring menjadi suatu hal yang biasa dilakukan pada saat ini, semua kegiaan dalam pembelajaran dilakukan secara online.

Menurut (Mu'alimah \& Ishafit, 2017) interaksi belajar secara daring dilakukan secara mandiri dengan memanfaatkan teknologi informasi dan pembelajaran yang telah disiapkan secara elektronik, dan dapat dilakukan kapan saja dan dimana saja. Kegiatan pembelajaran yang biasanya diakukan dengan tatap muka sekarang dilakukan secara online 
tanpa adanya batasan ruang dan waktu. Begitupun dalam pemenuhan informasi dalam pembelajarang daring tersebut, semua kebutuhan informasi lebih dominan terpenuhi oleh adanya teknologi, misalnya saja pemenuhan infromasi dalam bentuk e-book, jurnal online, website, digital library dan lainnya. Menurut (Isma) mahasiswa memiliki keleluasaan waktu belajar. mahasiswa dapat belajar kapanpun dan di manapun. Mahasiswa dapat berinteraksi dengan dosen baik secara synchronous - interaksi belajar pada waktu yang bersamaan seperti dengan menggunakan video converence, telepon atau live chat, maupun asynchronous - interaksi belajar pada waktu yang tidak bersamaan melalui kegiatan pembelajaran yang telah disediakan secara elektronik. Keterkaitan pemeblajaran daring dengan teknologi juga menuntut mahasiswa untuk memiliki kemampuan literasi yang baik. Hal ini bertjuan agar informasi yang didapatkan sesuai dengan kebutuhan dan dapat memiliah informasi yang tersebar, sehingga ini dapat dijadikan sebagai salah satu cara untuk terhindar dari informasi Hoax.

Proses temu kembali informasi saat ini sangat beragam salah satu yang dapat memudahkan proses temu kembali informasi adalah sistem "Search Operation". "Search Operation" adalah satu cara yang dapat diguankan dalam proses temu kembali informasi agar dapat menemukan informasi yang sesuai dengan kebutuhan. Metode "Search Operation" juga dapat dijadikan sebagai salah satu cara agar terhindar dari informasiinformasi yang tidak sesuai dengan fakta yang ada atau informasi Hoax, sehingga proses pencarian informasi akan lebih efekti dan infromasi yang didapatkan akan lebih akurat. Oleh karena itu metode "Search Operation" dapat diimplemtasikan oleh mahasiswa dalam proses pembelajaran daring untuk memoperoleh ]]informasi yang dibutuhkan.

\section{METODE}

Metodologi yang digunakan pada penulisan ini menggunakan kualitatif dengan menggunakan metode analisis deskriptif, yaitu metode yang mendeskripsikan data untuk mendapat kesimpulan secara umum. Menurut (Satori \& Komariah, 2014) pengertian dari penelitian kualitatif adalah penelitian yang menekankan atau memusatkan pada quality atau hal yang terpenting dari sifat suatu barang atau jasa.Hal terpenting dari suatu barang atau jasa berupa kejadian, fenomena atau gejala sosial yang memiliki arti dibalik kejadian tersebut yang dapat dijadikan sebagai pembelajaran yang berharga bagi suatu pengembangan konsep teori. Sedangkan menurut (Sugiyono, 2015) mengemukakan bahwa, "metode penelitian pada dasarnya merupakan cara ilmiah untuk mendapatkan data dengan tujuan dan kegunaan tertentu". Menurut (Sugiyono, 2015) pengertian deskriptif adalah 
penelitian deskriptif adalah penelitian yang dilakukan untuk mengetahui keberadaan variabel mandiri, baik hanya pada satu variabel atau lebih tanpa membuat perbandingan atau menghubungkan dengan variabel lainnya.Metode pengumpulan data menggunakan literatur dan observasi elektronik terhadap beberapa jurnal sesuai lingkup penelitian yang kemudian dianalisa menggunakan reduksi data, representasi data, dan penarikan kesimpulan sekaligus memberikan contoh pengimplementasian metode "Search Operation" pada beberapa operator atau sintaks dalam penelusuran informasi seperti boolean operator.

Berdasarkan latar belakang masalah yang telah dibahas pada pendahulan di atas, maka fokus dari pembahasan artikel ini adalah mengenai implementasi "Search Operation" dalam proses temu kembali informasi dan dampak penggunaan "Search Operation" terhadap pembelajaran daring khususnya bagi mahasiswa. Sedangkan tujuan dari artikel ini yaitu untuk meningkatkan literasi informasi mahasiswa dalam proses pembelajaran daring.

\section{HASIL DAN PEMBAHASAN}

Pembelajaran daring merupakan sistem pembelajaran yang melibatkan teknologi dan media internet. Saat ini pembelajaran daring sering digunakan dalam metode pembelajaran sebagai salah satu inovasi proses pembelajaran di era teknologi 4.0. Pembelajaran daring ini juga tidak asing lagi diterapkan dalam proses pembelajaran di perguruan tinggi. Dalam hal ini mahasiswa dituntut untuk dapat berinteraksi dengan baik terhadap proses pembelajaran daring tersebut. Selain itu untuk mendukung proses pembelajaran ini mahasiswa sebaiknya dapat menguasai teknologi yang berkembang saat ini, terutama perkembangan teknologi dalam bidang informasi. Mahasiswa diharapkan dapat menggunakan teknologi informasi semaksimal mungkin untuk mendukung proses pembelajaran daring. Tidak hanya itu, untuk dapat menggunakan teknologi informasi secara efektif dan efisien maka perlu adanya kemapuan literasi informasi yang dimiliki oleh mahasiswa. Literasi informasi adalah serangkaian kemampuan yang dibutuhkan seseorang untuk menyadari kapan informasi dibutuhkan dan memiliki kemampuan untuk mencari, mengevaluasi, menggunakan, dan mengkomunikasikan informasi secara efektif (Hasugian, 2008). Dengan demikian seseorang yang memiliki kemampuan literasi yang baik mampu memenuhi kebutuhan informasinya dengan tinggkat keakurtan yang tinggi.

Menurut (Muntashir, 2016) ada lima standar litetrasi informasi yaitu 1) Menetapkan kebutuhan informasi yang dibutuhkan, 2) Menemukan informasi yang dibutuhkan secara efektif dan efesien, 3) Mengevaluasi informasi dan sumber secara kritis dan menggabungkan beberapa informasi menjadi basis pengetahuan dan sistem nilai, 4) Secara 
individu maupun berkelompok menggunakan informasi untuk mencapai tujuan tertentu 5) Menggunakan informasi dengan memahami isu terkait budaya, ekonomi, hukum dan sosial terkait penggunaan informasi. Dengan memahami lima standard tersebut, maka akan memudahkan dalam mendapatkan infomasi yang dibutuhkan secara efektif dan efisien dengan tingkat keakuratan yang tinggi. Kemampuan literasi informasi juga berkaitan dengan proses pencarian informasi. Dalam sistem temu kembali informasi dikenal dengan istilah "Search Operation". Search Operation atau operasi pencarian merupakan strategi dalam proses temu kembali informasi untuk mendapatkan dokumen atau informasi secara akurat.

\section{Implementasi Search Operation dalam Proses Temu Kembali Informasi}

Dalam proses temu kembali informasi ada beberapa strategi yang dapat dilakukan baik itu temu kembali informasi yang dilakukan pada OPAC maupun pada database yang memuat berbagai informasi. Berikut ada beberapa cara yang dapat dilakukan dalam penelusuran informasi melalui metode search operation.

a) Strategi Penelusuran

Strategi penelusuran adalah sebuah cara yang dilakukan sebelum proses pencarian informasi dilakukan. Strategi tesebut dapat berupa pemilihan kata kunci ataupun penentuan tempat pencarian. Selain itu strategi pencarian juga berkaitan dengan kesiapan dalam melakukan pencarian informasi, kesiapan tesebut seperti pemahaman terhadap materi yang dicari. Pada dasarnya dalam strategi pencarian ini diperlukan kesiapan yang maksimal, sehingga jika terjadi masalah maka dapat mengatasinya dengan baik. Dalam hal ini perlu adanya obsi cadangan jika obsi pertama tidak berhasil.

b) Menggunakan Keyword

Penggunaan keyword atau kata kunci adalah hal yang paling penting. Dalam proses pencarian di OPAC kata kunci ini akan berkaitan dengan judul, nama pengarang, maupun editor. Pemilihan kata kunci yang tepat juga dignakan dalam proses penelusuran informasi pada database pencaian di internet. Pada dasarnya pemilihan kata kunci ini merupakan pemilihan kata yang mendekati karakteristik dari sebuah dokumen atau informasi yang dicari. Dokumen ata informasi akan muncul jika kata kunci yang digunakan sesuai atau mendekati karakteristik yang dimiliki oleh dokumen tersebut. Dalam operasi pencarian, pengimplementasian penggunaan kata kunci ini sangatlah penting. Keberhasilan memanggil 
dokumen atau informasi juga akan bergantung pada penggunaan kata kunci. Oleh sebab itu akan lebih baik mempertimbangkan penggunaan kata kunci yang tepat dalam proses pencarian informasi.

c) Menggunakan Tajuk Subjek

Tajuk subjek atau istilah baku juuga dapat digunakan dalam proses pencarian informasi. Penggunaan tajuk subjek ini sebagai sebuah perwakilan dari informasi yang sudah ditentukan polanya dengan kata lain sudah dibakukan dan ada institusi yang mengelolah serta menerbitkannya dalam sebuah daftar tajuk subjek yang umum maupun khusus.

d) Penggunaan Sintaks

Pada penelusuran dengan boolean logic, biasanya user dihadapkan dengan operator AND, OR, dan NOT. Operator AND, adalah operator penghubung dengan kondisi bahwa kata pertama dan kata kedua dalam OPAC akan dicari secara bersamaan atau berdampingan. Operator OR, adalah operator penghubung dengan syarat jika kata pertama dan kata kedua dicari dalam pencarian OPAC, maka pencarian akan mencari sesuatu yang mengandung kata pertama, atau kata kedua, atau yang mengandung kedua kata tersebut. Pernyataan yang diawali dengan NOT, berarti bahwa pernyataan tersebut mempunyai nilai yang tidak mengandung pernyataan yang disebutkan. Contoh: ketika user ingin mencari judul artikel yang tidak mengandung kata 'perpustakaan' maka user dapat mengetikkan kata 'perpustakaan' dan menggunakan operator NOT. Berikut akan diberikan contoh penggunaan AND dan OR (Dewi, 2018).

Penggunaan Boolen seperti, and, or, dan not sebagai salah satu cara untuk mengumpulkan suatu dokumen dengan topic pembahasan yang luas, penyempitan topik, dan pembatasan pada satu topic pencarian. Misalnya dalam contoh menggunakan kata kunci "management library" dan menyertakan Boolean Logic "AND" untuk mengumpulkan dokumen yang berhungan dengan managemen dan library secara luas. 


+Add Term

Search results -315 records

Can't find the UK doctoral thesis you want? Click here to ask our experts

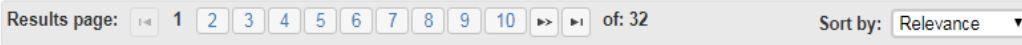

Issues in contemporary academic library management

Author: Revill, Donald Herington.

Awarding Body: Liverpool John Moores University

$\dddot{\varnothing}$

Awarded: 1997

Personnel management practices in Kuwait libraries

Author: Al-Hasan, Sulaiman

Awarding Body: Loughborough University of Technology

Awarded: 1992

Gambar 1. Penggunaan Boolean AND

Berikut peenggunaan "OR", dimana hasil pencarian akan keluar salah satu dari kata kunci yang digunakan. Misalnya kata kunci " financial management", maka hasil yang ditemukan adalah management ataut financial.

$\therefore \rightarrow$ C ethos.bl.uk/SearchResults.do

Financial management
$\mathrm{OR}$ Limit search to items available for immediate download

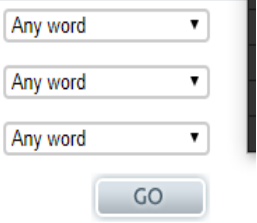

Limit search to items available for immediate download

Search results - 37031 records

Can't find the UK doctoral thesis you want? Click here to ask our experts

\begin{tabular}{ll|l|l|l|l|l|l|l|l|l|l|l|l|l|l|l} 
Results page: & if & 1 & 2 & 3 & 4 & 5 & 6 & 7 & 8 & 9 & 10 & $\rightarrow$ & of: 3704
\end{tabular}

Optimal Decision Techniques in Financial Management.

Author: Barron, M. J.

Awarding Body: University of Southampton

Awarded: 1975

Risk management using derivatives.

Author: Aas, Roar

Awarding Body: Heriot-Watt University

சே

Awarded: 1993

Local financial management in a primary school: The Cambridgeshire scheme. 
Penggunaan "NOT" yang berarti pencarian tersebut hanya memunculkan salah satu kata kunci, maka kata kunci yang ditambahkan "NOT" tidak akan ditampilkan oleh database pencarian.

\section{Dampak Penggunaan "Search Operation" terhadap Pembelajaran Daring Khususnya bagi Mahasiswa}

a) Memudahkan dalam Proses Pencarian Informasi

Dengan meggunakan teknik dalam pencaian informasi maka akan memudahkan dalam menemukan informasi yang ingin dicari. Hal ini disebabkan karena dalam proses pencarian melakukan strategi yang matang, sehingga jika terjadi kendala akan mudah mengatasinya. Pembelajaran daring yang saat ini sangat popular akan terbantu dengan adanya teknik search operation ini. Tingkat keakuratan informasipun akan lebih baik jika dibandingkan dengan proses pencarian informasi tanpa teknik. Sebagaimana yang kita tahu informasi tersebar dalam jumlah yang banyak dengan jenis yang beragam, maka aka ada kemungkinan kita kesulitan dalam memilih informasi yang sesuai dengan kebuthan. Search operation dapat dijadikan salah satu cara yang efektif untuk menyelesaikan permasalahan tersebut.

b) Menghindari Dokumen atau Informasi yang Tidak Relevan

Penggunaan teknik search operation akan menghindari dokumen yang tidak relevan. Dalam proses pembelajaran daring mahasiswa akan dihadapkan dengan pengolahan informasi, dimana informasi tersebut lebih banyak diperoleh melalui internet. Banyaknya informasi yang ada di internet tentu tidak semua informasi tersebut sesuai dengan kebutuhan. Bahkan banyak informasi yang tersebar dengan menggunakan judul yang menarik, namun tidak memiliki kandungan isi yang sesuai. Selain itu juga terdapat ketidaksesuian antara judul yang digunakan dengan isi yang dibahas. Penggunaan search operation dapat dijadikan salah satu cara selain menganalisa keserluruhan isi informasi tersebut. Dengan kata lain teknik yang ada pada search operation merupakan cara cepat yang dapat dilakukan dengan tetap mempertimbangkan keakuratan informasinya. Penggunaan search operation akan menghubungkan mahasiswa secara 
langsung dengan informasi yang dicari dengan demikian akan langsung dihadapkan dengan informasi yang sesuai misalnya dengan penggunaan Boolean.

c) Proses Temu Kembali Informasi Akan Lebih Cepat

Penggunaan search operation akan membuat proses temu kembali lebih cepat, maksudnya adalah mahasiswa dapat menemukan informasi lebih cepat karena adanya bantuan dari teknik pencarian pada penggunaan search operation. Dalam proses pembelajaran daring teknik ini akan membantu mahasiswa dalam menemukan informasi yang dibutuhkan.

d) Tingkat Keakuratan Informasi Akan Lebih Tinggi

Dengan adanya penggunaan search operation akan menambah mahasiswa menemukan informasi dengan tingkat keakuratan lebih tinggi. Hal ini disebabkan karena teknik yang ada pada search operation secara tidak langsung telah membantu mahasiswa menyeleksi informasi yang dicari dari beragamnya informasi yang tedapat dalam sebuah database. Maka dari itu mahasiswa harus dapat memanfaatkan teknik search operation dengan sebaik mungkin. Dari berbagai metode yang terdapat dalam search operation mahasiswa dapat mengimplementasikan satu diantaranya. Keakuratan informasi yang diperoleh akan bergantng pada bahasa pemanggilan yang digunakan, dengan demikian perlu adanya pemilihan kata yang tepat dan menggabungkan dengan salah satu dari metode pada search operation.

e) Mengasah Kemampuan Literasi Informasi

Implementasi dari search operation akan mengasah kemampuan literasi informasi mahasiswa. Kemampan literasi tersebut akan terlatih jika mahasiswa sering melakukan analisa terhadap kebutuhan informasinya. Search operation tidak hanya memudahkan mahasiswa dalam menemukan informasi, namun juga akan mengarahkan mahasiswa untuk berpikir sebelum betindak. Hal ini bekaitan dengan penyusunan strategi yang dilakukan sebelum dilakukannya proses pencarian. 


\section{PENUTUP}

\section{Simpulan}

Setiap mahasiswa perlu memiliki kemampuan literasi agar informasi yang diinginkan dapat terpenuhi sesuai dengan kebutuhan. Kemampan literasi ini akan terlihat ketika melakukan kegiatan temu kembali informasi. Dalam proses temu kembali informasi banyak cara yang dapat dilakukan salah satunya dengan menggunakan metedo yang ada ada pada search operation. Pencarian informasi dalam hal ini tentunya berhubu ngan dengan penggunaan teknogi. Selain itu adanya temu kembali informasi melalui search operation akan membantu mahasiswa dalam proses pembelajaran daring. Dimana pembelajaran daring saat ini didukung oleh teknologi. Pembelajaran daring, teknologi, dan pemenuhan informasi merupakan satu kesatuan yang saling berhungan, salah satunya yaitu dengan adanya implementasi temu balik informasi melalui search operation. Dimana ada beberapa cara yang dapat digunakan dalam temu balik informasi melalui search operation yaitu strategi penelusuran, menggunakan keyword, menggunakan tajuk subjek dan penggunaan sintaks. Dari beberapa cara tersebut dapat digunakan dalam proses temu kembali informasi. Penggunaan search operation akan memberikan dampak dalam proses pembelajaran daring diantaranya yaitu Memudahkan dalam proses pencarian informasi, menghindari dokumen atau informasi yang tidak relevan, proses temu kembali informasi akan lebih cepat, tingkat keakuratan informasi akan lebih tinggi dan mengasah kemampuan literasi informasi.

\section{Saran}

Dengan adanya sistem temu kembali informasi melalaui search operation diharapkan mahasiswa dapat mengimplementasikannya dengan baik, terutama dalam pembelajaran daring. Mahasiswa juga diharapkan terus mengasah kemampuan literasi informasi dan dapat memanfaatkan teknologi dengan sebaik mungkin.

\section{DAFTAR PUSTAKA}

Dewi, A. O. (2018). Pencarian Katalog Dalamonline Public Access Catalogmenggunakan Boolean Logic. Jurnal Anuva, 294.

Hasugian, J. (2008). Urgensi Literasi Informasi Dalam Kurikulum Brbasis Kompetensi Di Perguruan Tinggi. Jurnal Studi Perpustakaan Dan Informasi , 36.

Isma, M. Pembelajaran Moda Dalam Jaringan (Moda Daring). Sumatera Utara: Universitas Muhammadiyah Sumatera Utara . 
Mu'alimah, H., \& Ishafit. (2017). Pembelajaran Inkuiri Kolaboratif Daring Dengan Media Social Whats App Pada Kemampuan Komunikasi Terhadap Materi Kalor Bagi Peserta Didik Di Abad 21. Yogyakarta: Univeristas Pgri Madiun .

Muntashir. (2016). Standar Kompetensi Literasi Informasi Mahasiswa Ilmu Perpustakaan Pada Perguruan Tinggi Agama Islam . Jurnal Ilmu Perpustakaan Dan Informasi, 105.

Satori, D., \& Komariah, A. (2014). Metodelogi Penelitian Kualitatif. Bandung: Alfabeta.

Sugiyono. (2015). Metode Penelitian Kombinasi (Mix Methods). Bandung: Alfabeta. 